\title{
Using legal language as a non-lawyer: Danish lay judges' linguistic strategies during criminal trials
}

\section{Louise Victoria Johansen}

Lay participation in criminal trials has primarily been studied in common law systems, thereby mainly focusing on the separate role of juries. These studies have provided detailed accounts of language use between jurors during deliberation as well as their use of storytelling techniques and common-sense reasoning in decision-making. However, only few studies have focused on the linguistic learning processes that lay judges in other legal systems go through when they deliberate cases TOGETHER with a professional judge both in reaching a verdict and in sentencing. In Denmark, lay judges are appointed for a period of four years, and this paper presents findings from an ethnographic study of lay judges and their growing experience with interactions in the deliberation room. It argues that lay judges learn to use legal language in order to strengthen their arguments vis-à-vis the professional judges. Lay judges feel that their influence is dependent on how well they master new, legal context-specific ways of expressing themselves, a point that may run counter to their legitimation as lay voices in an otherwise formalized judiciary.

Keywords: communities of practice, criminal trials, discourse analysis, lay judges, legal language, situated learning

Louise Victoria Johansen, University of Copenhagen, Faculty of Law, Karen Blixens Plads 16, 2300 Copenhagen S, Denmark.

Louise.Victoria.Johansen@jur.ku.dk

\section{INTRODUCTION}

In a Danish setting, lay judges are appointed for a four-year period which may be extended several times - a way of organizing lay participation that is similar to that in other Scandinavian countries and Germany (Diesen 1996, Lundmark 2012). The present article addresses the ways in which Danish lay judges' influence is dependent on their acquisition of new ways of expressing themselves orally and through note taking. It adopts an analytical combination of discourse theory (Fairclough 1992), linguistic anthropology (Philips 1988, 2010; Mertz 2007), and a learning theory approach (Lave \& Wenger 1991) in order to analyse the development of lay judges' strategic use of language during deliberation. This development implies that lay participation is also an acquired skill, and most lay judges in the present study 
have described how they shifted focus somewhat as they gained experience. The analysis is based on authentic case data from 60 criminal trials with unique access to all deliberations and involving 30 lay judges over a three-year period. It focuses ethnographically on the ways in which lay people change their linguistic behaviour during their familiarization with legal settings. Although the issue of developing identities was at the forefront of my research project, it quickly became apparent through observations as well as interviews that lay judges themselves focused on language, notes, details, and their conversations with judges. Linguistic anthropology has focused on this kind of linguistic reflexivity as a way in which people consider their own language use to understand their current practices and contexts (Mertz 2007), also called a 'meta level' of language. Consequently, the present analysis focuses on both the conversations between lay judges in the deliberation room, and on their reflections formulated in interviews about their developing language skills in a legal setting.

The role of language for lay decision-making in the judiciary has primarily been studied in common law systems. This research has mainly looked at juror interaction, for example the ways in which jurors evaluate evidence together (Kuhn, Weinstock \& Flaton 1994, Conley \& Conley 2009), as well as their reference to common sense (Garfinkel 1967, Manzo 1994) and argumentation patterns (Diamond et al. 2003, Warren, Kuhn \& Weinstock 2010). For instance, jurors have been shown to use storytelling to influence fellow jurors (Pennington \& Hastie 1991, Heffer 2008). Other studies focus on the interaction between lay and legal language as expressed for instance in juries' reception of instructions (Heuer \& Penrod 1989, Heffer 2008), as well as the ways in which other legal actors, such as the defence and prosecution, address the jury in court (Piecker \& Worthington 2003). Implicit in many of these studies is the obvious condition that jurors and judges do not interact during deliberation, which brings juror decisions to the fore of the research.

In contrast to this focus on juror interaction, lay judge participation, which is prevalent in civil law systems, presents us with different problems because of the simultaneous interaction between lay and professional judges, and lay judges' often longstanding commitment to this civic duty (Johansen 2017). Although subject to some variation, jurors in the United States will typically be summoned for a oneor two-month period for trial juries. Danish lay judges are summoned for a much longer four-year period and serve at least four-to-eight times a year. This cumulative experience is surprisingly underexposed in socio-legal literature, although I will argue that its implications for lay decision-making are crucial. Danish lay judges have up until now been studied through two quantitative studies (Eyben 1969, Wilhjelm 1988) and one qualitative study (Malsch 2009), focusing on their general view on this civic role, but without addressing possible developments in their perceptions and identities, let alone their understanding of the linguistic aspects of law-making.

After presenting the data set and the analytical framework, the article proceeds to analyse lay judges' practices. To start with, the empirical examples centre on 
inexperienced lay judges' practices in an unacquainted legal world; subsequently, the examples show how gaining experience teaches lay judges to interact with professional judges by adjusting their notes and expressing themselves differently than before. In the conclusion and perspectives section (Section 6 below), I discuss the implications for a democratic legal justice system and issues for further research.

\subsection{Lay judges and their role in a Danish legal context}

The Danish legal tradition is often characterized as being part of a separate Nordic legal family, but more closely related to Continental civil law systems than to common law systems (Tamm 2008). The Danish lay judge system, introduced in 1937, was modelled on its Continental counterparts (Anderson 1990). The use of lay judges is most widespread in civil law systems and in Nordic law, whereas the jury plays a central role for common law jurisdictions. In Denmark, lay judges only participate in criminal cases, although they do not participate at the Supreme Court level, but only at district and high court level. The present study focused on the district courts, of which there are 24 in Denmark. At this level, two lay judges and one professional judge participate in criminal cases where defendants have pled not guilty and the prospective sentence is four years or less. ${ }^{1}$ Judges and lay judges have equal votes in the decision-making during deliberation concerning both the verdict and the sentence. Decisions are arrived at by simple majority.

Lay judges are not allowed to ask questions in the courtroom, but the professional judge can formulate a question on behalf of them. Only the professional judge has full access to case files and evidence such as pictures, but this evidence will be shown to lay judges if it is presented in court. Anyone between 18 and 66 years old can become a lay judge if they have the right to vote for the Danish parliament and have a clean criminal record. ${ }^{2}$ Recruitment aims at being as broad as possible. ${ }^{3}$ No instruction is given to lay judges before they attend their first case apart from a welcome meeting at the district court. When they meet in the deliberation room before each case, the professional judges will ensure that the newcomers feel at ease and have the necessary information to participate. Apart from this brief introduction, the more experienced lay judges often serve as mediators between the legal system and the lay persons entering this context for the first time (Johansen 2017). Therefore, it is important to be aware that the deliberation room is not only the site of formal exchanges about the trial between judges and lay judges, but also of informal talk about for instance experiences from other cases, the role of lay judges, etc.

\section{METHOD AND DATA}

The ethnographic fieldwork began in 2012, which also marked the beginning of a new four-year lay judge period. I was able to follow 30 new lay judges during 
their first experiences with decision-making in criminal trials in a district court with approximately 1200 assigned lay judges. The final part of the fieldwork took place one-and-a-half years later.

It was not possible to select lay judges with specific social profiles for the project, since they were randomly selected as the next on the official list. As it happened, fourteen of the lay judges were men and sixteen were women. Five lay judges were 30 years old or younger, ten lay judges were between 30 and 40, six lay judges were between 40 and 50, another five were 50 to 60 years old, and four were more than 60. About one-third had a short or no higher education, another one-third had a medium-long education (for instance a bachelor degree), and the rest had a master's degree. The criminal trials were about simple or aggravated assault, theft, fraud, and minor sale of narcotics. ${ }^{4}$

Permission to approach the lay judges was approved by the chief justice of the court, but both professional and lay judges have individually given informed consent to participate in the project. They were all aware of the project's affiliation with the University of Copenhagen and its aim of describing how lay judges perceive their civic duty over an extended period of three years. All participants and cases have been anonymized to prevent recognition by other parties. Finally, it should be noted that the article focuses on the process of deliberating, and not on the verdict itself.

Observations were carried out in the courtroom and in the deliberation room. Since audio recording during deliberation was not allowed, my observations were noted down in as much detail as possible and written into field notes after each case. These field notes aimed at accurately reporting exchanges during deliberation and sought to quote directly most of what was said in the deliberation room. I interviewed the lay judges after each case, and the interviews lasted between 45 and 90 minutes. All interviews were recorded and transcribed. ${ }^{5}$

The interviews focused on the observed cases as well as on lay judges' general experiences with their role in the court. Since the second interview took place more than a year after our first meeting, these second encounters also involved their reflections as to what had changed. Their ability to speak about their own practices and experiences is therefore also a product of the interview situation itself, since it encouraged lay judges to reflect about their changing roles and as such to become conversation partners and not just passive respondents (Chase 1995).

\section{ANALYTICAL FRAMEWORK}

The analytical framework addresses different aspects of how lay judges developed their understanding of the role of language in a legal setting. It describes relationships between language, knowledge and identity by combining a discourse analysis of 
lay judges' talk with theories about their learning processes in a specific cultural environment.

Norman Fairclough's critical discourse analysis (CDA) highlights the linguisticdiscursive dimension of lay judges' statements as a cultural and social phenomenon (Fairclough 1992). Fairclough's discourse analysis is complex and embraces different theoretical approaches such as linguistics, ethnomethodology, and macrosociology (Fairclough 1992:72, 100), but will only summarily be presented here. The article focuses on Fairclough's three-dimensional model of language use. One dimension is a TEXT analysis of specific written and spoken utterances, and this part of the analysis is predominantly descriptive, focusing on the properties of texts. ${ }^{6}$ Secondly, utterances form part of DISCURSIVE PRACTICES, because participants must use existing discourses in order to be able to formulate a meaningful utterance in a specific social or institutional context. The last dimension involves the relationship between discourse and SOCIAL PRACTICE, in the sense that discursive practices may reproduce or challenge the social context in which language is used.

Applied to the present analysis, I consider lay judges' utterances in interviews as well as during observations as a 'text' with particular linguistic properties. At this level of textual analysis, Fairclough uses the concept of modality to describe how people identify with their own statements to varying degrees by using different levels of affinity with their statements, for instance from an assertive, He stole the bag, to a more insecure, He may have stolen the bag, or even, I think he stole the bag. He also identifies 'hedges' that signal vagueness such as a bit, or kind of. As we shall see later, lay judges eventually learn to discern between assertive and insecure statements from witnesses and to use these modalities in their evaluation of witnesses' credibility.

Lay judges' utterances as 'discursive practices' are analysed by discerning the ways they learn to draw on existing discourse used in this particular legal context.

Finally, I discuss how their socialization into legal language forms part of broader social interests and positions. For instance, other judges may tell lay judges that evidence such as crumpled banknotes found in a defendant's pocket implies drug dealing. This verbal exchange addressing banknotes indicates a social knowledge about links between specific objects, persons, and actions. Such social knowledge also ascribes social positions to people such as a 'drug dealer'. We may thus identify possible connections between the language of deliberation, the social knowledge it draws upon, and the possible actions it results in.

Fairclough's concepts are highly applicable to a legal context in which not just WHAT is said but HOW it is said forms a crucial part of decision-making. In addition, Fairclough's own theoretical connection between discourse and broader social practices and power relations has been explored extensively in other empirical studies of legal contexts. For instance, studies of trials have highlighted communication processes between legal experts and non-experts, and between lay and legal language. Anesa (2012) describes how the communicative roles of lawyers and jurors are 
clearly distinct and highly dependent on their professional membership and personal backgrounds, possibly leading to knowledge asymmetries, different communicative strategies and techniques (Anesa 2012:52). These themes have also surfaced in studies of American small claims courts, describing the ways in which lay people orient themselves linguistically in court (Conley \& O'Barr 1990, Merry 1990). For instance, the language of courts and judges is mostly 'rule oriented' (Conley \& O'Barr 1990), focusing on facts and logical sequences as regards events, time, and places. Lay people, on the other hand, talk about conflicts in great detail and emphasize their social relations with the people they are in conflict with, an aspect legal actors often find irrelevant (Conley \& O'Barr 1990). Courtroom interaction studies have shown how legal actors try to reorient this kind of 'lay talk' by interrupting witnesses and asking for precision regarding times, places, etc. (Atkinson \& Drew 1979, Conley \& O'Barr 1990). Discourse analyses have also shown how differences in courtroom speech styles may affect legal outcomes (Conley, O'Barr \& Lind 1978, O’Barr 1982). In these studies, lay people who employed a vague or powerless speech style characterized by e.g. hesitation or modifiers such as sort of were ascribed less credibility by courts than people who spoke more assertively with only few unnecessary words. However, the consequences of 'powerless' speech may not always be as clear-cut. For instance, a study of Danish criminal trials points to the fact that witnesses employing powerless language may nevertheless seem more trustworthy to courts than assertive speakers (Mortensen \& Mortensen 2017).

Irrespective of the conclusions that have been drawn from these studies, there is a tendency to associate lay language with jurors and other lay participants, and to see legal language as the unique domain of lawyers. However, this somewhat static approach seems to overlook the fact that lay judges are not passive actors and that they may develop their knowledge and skills in this legal setting. I use Lave \& Wenger's (1991) learning theory to analyse the development of new skills in an unfamiliar setting, and to bridge the gap between lay and legal domains of knowledge. Lave \& Wenger use the concept 'situated learning' to explain how individuals learn professional skills by participating in 'communities of practice' through a process called 'legitimate peripheral participation' (Lave \& Wenger 1991:29, 49) - a kind of membership in constant development. As a newcomer in an already established community, people learn by interacting with more experienced members (such as lay judges with more than four years' experience) and professionals (such as judges). Although Lave \& Wenger do not focus specifically on the linguistic aspects of learning, their theory implicitly addresses these kinds of processes.

Linguistic anthropologists, however, regard language as a crucial vehicle for the transmission of cultural knowledge, and their linguistic studies are concerned with addressing the use and context of language (Hymes 1971). Research projects about language socialization have studied different life situations such as children's language acquisition, and professional language in law and medicine, also described 
as a secondary language socialization (Mertz 2007). For instance, law students attending American universities learn new ways of talking and writing as well as a 'deeper level of specificity' in their ways of describing cases, facts, etc. (Philips 1988, Mertz 2007), a learning process that shifts their attention away from social problems and on to legal issues. Similarly, I consider lay judges' learning process as a relationship between linguistic socialization, competence, and identity, and I analyse how changes in language use may affect their understanding of cases, evidence, etc. Interestingly, there is no explicit learning at stake in the courthouses, and professional judges often underscore the fact that lay judges 'shouldn't know anything'. Still, a lay judge who literally did not know anything about criminal trials in his or her fourth year would probably be met with mild irritation by the other judges (Johansen 2017). This leaves it to lay judges themselves to navigate in this community of practice, and to try to figure out, at a meta level, what kinds of discursive practices they are engaging in.

\section{ANALYSIS}

\subsection{Newcomers in a legal community}

Lay judges typically felt quite overwhelmed by their first cases, nervous about not fulfilling their task well enough, and surprised at the fact that it was so very difficult to judge another person. They felt included during deliberation, but also had a vague feeling that they were not able to express their disagreement as forcefully as they probably would after gaining more experience (Johansen 2017). This 'peripheral' participation as also described by Lave \& Wenger (1991) is the starting point for most newcomers in established communities of practice. Many aspects of learning are included in this process for lay judges, some of which involve orienting themselves physically in the courtroom, getting used to judging, and learning to understand a case so as not to lose oneself in (apparently) insignificant details. In the following, this latter aspect of linguistic peripherality will be addressed, showing how lay judges are informally socialized into being able to express themselves and state their opinion by presenting only its essential points.

My observations showed that lay judges participating in the present project took copious amounts of notes during their first trials; most of them returned from the courtroom with anything from five to ten closely written pages. Only one lay judge did not take notes at all, and another just jotted down some major points. All professional judges without exception took notes in every case observed.

Very few studies about jurors have addressed the issue of note taking for the simple reason that this is not allowed for jurors in an American context. They must rely on their memory and nothing else. Some social psychological studies have 
tested what happens when jurors are allowed to take notes; their results indicated that juror participation and satisfaction were strengthened. Some of these conclusions are relevant to the present project, for instance that jurors' satisfaction actually rose when taking notes, and that they felt more involved in and more able to influence decisions. More inconclusively, jurors' ability to take notes was registered both as unevenly distributed (Flango 1980, McLaughlin 1982), and at the same time not dependent on their educational background (Heuer \& Penrod 1988). However, these studies did not follow jurors through more than one case; consequently, we know little about civil law lay judges and their developing linguistic skills in note taking.

In Denmark, every lay judge is provided with large sheets of paper and pencils before each case. There are, however, quite strict rules regarding these notes - they must never leave the court and are destroyed after the conclusion of each case. ${ }^{7}$ At no point during the 60 cases I observed in the deliberation room and in the courtroom did I hear a professional judge address the issue of taking notes, let alone tell lay judges if they thought it was a good idea to engage in this practice or not. Nor did more experienced lay judges mention this directly, although we shall see later that they do communicate their own note taking experiences. Basically, each lay judge must individually make up his or her own mind whether to take notes, how to take them, and what to note down. An example of lay judges' first experiences with note taking is presented in (1) (LJ = lay judge; in this and other examples, the Danish text (in italics) is followed by my English translation).

(1) Lay Judge 1 (LJ1): Ja altså, $i$ starten, der sad jeg også de første gange narmest og stenograferede det hele, ikke. Altså, alt det de sagde, jeg sad bare og skrev og skrev og havde måske svart ved ligesom at koncentrere mig om at lytte og egentlig forstå, hvad det var, der blev sagt, fordi man havde så travlt med at sidde at skrive det hele ned, fordi man ville, man ville ikke miste noget ...

Lay Judge 1 (LJ1): 'Well, in the beginning, I also sat there the first few times more or less writing everything down verbatim in shorthand, you know. I mean, everything they said, I just wrote and wrote and then maybe found it difficult to concentrate properly just on listening and really understanding what was being said, because you were so busy writing everything down, because you didn't, you didn't want to miss anything ...' (1. interview, 2012)

LJ1 mentions how he wrote almost everything down, impeding his understanding of what was being said in the courtroom. ${ }^{8}$ Other lay judges also described how they wrote everything down in the first cases that I observed. This practice reflected the fact that lay judges are not given any guidelines before their first cases; consequently, they all engaged in the same practice of notetaking but without a clue about how to carry it out. This insecurity was related to the fact that they did not yet know 
what kind of discursive practice they were engaging in (see Mertz 2007), and therefore wrote everything down without considering its content or its directional value.

In the following passages, three lay judges talk about WHAT they noticed and wrote down during the first cases $(\mathrm{I}=$ interviewer):

(2) I: Jeg så, at du skrev noter i dag ...

LJ2: Ja, jeg tonkte på, om man skulle gøre det, men så gjorde den anden domsmand det, og så tankte jeg "nå ja men det er meget rart”. Og så har jeg fundet ud af, at alle de ting, som jeg skrev ned, de er for så vidt ligegyldige, men alligevel så forsøger jeg at lave mine konklusioner undervejs, og der er det meget rart at kunne se, nå men hvad var det, jeg skrev.

I: 'I saw that you were taking notes today ...'

LJ2: 'Yes, I was thinking about whether you were supposed to do it, but then the other lay judge did, and so I thought, "well yes, that's kind of nice". And then I realized that all the things I wrote down, they were sort of unimportant, but I still try to draw my own conclusions along the way, and then actually it is quite nice to be able to see, well what did I write down.' (1. interview, 2012)

(3) LJ3: For eksempel det med at hun [anklageren] navnte, altså jeg var meget interesseret $i$ beløbene $i$ dag, og da anklageren laste dem op, så skrev jeg dem ned, for ligesom at have det, og hvad der var blevet købt for, det skrev jeg også ned, for jeg tankte, det har en eller anden betydning.

LJ3: 'For instance what she [the prosecutor] mentioned, well I was very interested in the amounts [of money] today, and when the prosecutor read them aloud, I wrote them down, just to kind of have it, and how much had been bought, I also wrote that down, because I thought it might mean something.' (1. interview, 2012)

(4) LJ4: Jeg skriver det, som jeg mener er vigtigt fra, det jeg, (pause), der sorterer jeg, så jeg ikke får skrevet det hele ned. Men det er også sådan lidt, jeg troede for eksempel, at det kunne vare vigtigt, hvad han [tiltalte] selv troede.

LJ4: 'I write down what I think is important from what I (pause), I pick and choose, so that I don't write everything down. But it's also a bit, for instance I thought it might be important, what he [the defendant] himself thought.' (1. interview, 2012)

These lay judges describe how they try to find out what is important. Interestingly, they all more or less directly conclude that what they have noted down does not seem as relevant during deliberation as it did in the courtroom when they wrote it. They express this through utterances such as, 'for instance I thought it might be important, 
what he [the defendant] himself thought' (LJ4, example (4)), inviting the inference 'but it wasn't'. Similarly, Lay Judge 3 says 'how much had been bought, I also wrote that down, because I thought it might mean something'. They sense that some details might be more important than others, but do not have a full picture of what really constitutes an important detail in a case. They try to find the clues, one way being 'trial and error', as Lay Judge 2 describes it when he looks through his notes after deliberation and observes that, 'all the things I wrote down, were sort of unimportant' (example (2)). This self-recognition forms part of learning what kinds of elements will or will not be of any potential use. Learning as a lay judge happens in specific contexts directed at specific kinds of interaction during deliberation, and this is where lay judges want to perform well.

But what does it mean when something is 'unimportant' or on the other hand 'means something'? We gain more insight into this by looking at the interaction between lay judges, and how they retrospectively describe their past practices and compare them with the experience they have gained after two years. This will be analysed in the following section.

\section{LEARNING THE VALUE OF LINGUISTIC PRECISION}

Generally, interviews conducted at later stages showed that lay judges still took notes, but they consistently stated that their WAY of writing notes had changed. The present section will analyse examples of these changes and how they occurred.

New lay judges are not told directly that their comments or notes are wrong (see Lave \& Wenger 1991), but they do find that their arguments are more easily dismissed if they do not 'fit' within established bodies of knowledge in this context. In one case I observed, a new lay judge had noted down that the prosecution had cited a phone call as evidence of the defendant's guilt, but information had also surfaced that this phone number was not the defendant's at all. The new lay judge mentioned this fact during deliberation, pointing at her notes. The other, more experienced, lay judge remarked, 'These kinds of people often have more than one cell phone' (field notes, 2012). Although the phrase 'these kinds of people' was not further elaborated on, it clearly implied a category of people different from others - and different from the categories to which the lay judges themselves belong. Similarly, another new lay judge was sceptical about the fact that a supposed drug dealer was confronted with evidence that he was carrying a bunch of banknotes in his pocket at the time of his arrest. He claimed that he had just withdrawn them from a bank. The lay judge asked why this was not taken into account at all, and the professional judge explained that this was usually a sign of drug dealing because the notes had been crumpled. Even though we cannot conclude anything as to whether this kind of information will influence these lay judges in future cases, there was a tendency for new lay judges to 
be indirectly corrected about the value - or worthlessness - of the kinds of facts they had noted down.

This knowledge transmission happened at an evidentiary level, but more general experiences were also exchanged in the deliberation room. In his first case, a new lay judge came in and told the other lay judge how he had written a massive amount of notes, and the other, experienced, lay judge answered as in (5):

(5) LJ5: Det gjorde jeg også i begyndelsen, men nu ved jeg hvad der er vasentligt, og så skriver jeg kun det ned.

LJ5: 'I also did that in the beginning, but now I know what is important, and so I only write that down.' (Field notes, 2012)

In this citation, the experienced lay judge confirms that this is what one might experience in the beginning, but also points to the fact that this practice does (and should) change. 'Now I know what is important' is a statement that underscores the ignorance of the new lay judge.

Lave \& Wenger (1991) refer to an example from observed Alcoholics Anonymous meetings where new participants learnt how to tell their own addiction story by listening to more experienced participants and gradually adapting their narrative style to this community of practice. This is a promising way of regarding lay participation in the judiciary as well, because it directs attention to the informal learning of convincing ways of speaking in a legal context and in interactions with legal actors. Lay judges set out with a limited knowledge of WHAT to emphasize and HOW to emphasize it, but quickly adjust to the new expectations.

In the following excerpt, the lay judge explicitly addresses the development in her note taking practices and what she notices now:

(6) LJ6: Jeg skriver stadig, men i stikordsform eller sådan afgфrende vendinger. Altså for eksempel, der hvor jeg tankte, at han [tiltalte] siger det der med "det passer meget godt". Det er der, hvor jeg tanker, der er i hvert fald usikkerhed eller noget; og "jeg plejer at spare op" og så parentes ”Jeg mente, at der var penge nok på kontoen", og det er sådan nogle små citater.

LJ6: 'I still write notes, but just using keywords or like key phrases. Like, for instance, when I noticed that he [the defendant] says, "that's probably right". 9 That's when I think there is at least uncertainty or something; and "I usually save up", and then in brackets, "I thought there was enough money in my bank account", and it's like those kinds of short quotes.' (2. interview, 2013)

This lay judge is quite detailed in her notes, and she has a systematic approach whereby, for example, she notes words and phrases signalling uncertainty, and uses parentheses to show how a phrase might be connected with or back up a previous statement. Accordingly, she notes down the uncertainty that this defendant seemed to 
be communicating during the observed case in court, for instance the fact that he does not seem to remember some details and says, 'that's probably right' when confronted by the prosecutor. She also notes the defendant's phrases such as 'I usually', and 'I thought'. Analytically speaking, she seems to notice language use associated with 'modality'. According to Halliday (1994:358-359) and Fairclough (2003:170-171), modality includes adverbs such as the English usually, often, etc. Modality also refers to the fact that people may express high or low affinity with their propositions, for instance through modal adverbs such as probably, definitely, etc. In the following citations, other lay judges are grappling with the same kind of language issues about defendants' and witnesses' precision, or lack thereof, in their utterances:

(7) LJ7: Jamen, jeg skriver direkte ned, hvad der bliver sagt, fordi nogle af svarene, som enten et vidne eller den tiltalte giver, skriver jeg det ned, for så når man sidder derinde, så kigger jeg: "Jamen, det var ikke det han sagde, han sagde sådan og sådan. Ville han ikke have formuleret det anderledes, hvis det var?" Altså hvor, det gjorde jeg jo ikke i starten, så var det sådan lidt stikord, og så kunne jeg godt se, nå ja, det kunne godt have varet vasentligt, hvordan det var formuleret. Altså han sagde ikke bare "jeg er uskyldig”, han sagde et eller andet, ikke.

LJ7: 'Well, I write down exactly what is said, because some of the replies that either a witness or the defendant gives, I write those down, because then when you're sitting in there, then I look, "But that wasn't what he said, he said this and this. Wouldn't he have worded it differently otherwise?" And I didn't do that in the beginning, then it was just some keywords, and then I could see, well, it might have been important how it was worded. You know, he didn't just say, "I'm innocent"; he said something else, right?' (2. interview, 2014)

(8) LJ4: Ja jeg lagger vagt på, altså narmest sådan både ordbrug og sådan, fordi det synes jeg mange gange $i$ voteringen, der har det-der toeller det alligevel lidt. Hvordan det blev sagt, ikke? Så var det sådan lidt, jamen sagde han ja eller nej? Hvor han sagde 'joh, ja', men der er forskel på, hvordan man siger ja. Om det er et tøvende ja, eller det er sådan et... [ufærdig sætning; LVJ]

LJ4: 'Yes, I think it's really important, like word use and that sort of thing, because I think that often during deliberation, it has - it does actually make a bit of a difference. How it was said, yeah? It was a bit like, well did he say yes or no? When he said, "well, yes", but there is a difference in HOw you say yes. If it's a hesitant yes, or kind of a ... [unfinished clause; LVJ]' (2. interview, 2014)

In an American context, Susan Philips notes that legal professionals expect jurors to be 'fact finders' and to take notice of all presented details, including not just what was said but how it was said (Philips 1993:257). This is what Danish lay 
judges learn to notice: not just whether the defendant said that he was innocent, but HOW he said it (LJ7, example (7)). Similarly, they learn to note if a person says yes but uses hedges making it seem more hesitant (LJ4, example (8)); or if defendants and witnesses use phrases such as 'I thought' (LJ6, example (6)). What these lay judges are simultaneously describing is their own skills development. They evaluate defendants' and witnesses' affinity modality as being low or high (Fairclough 1992:142), and use this as a way of constructing their own social identities as 'fact finders' in a legal setting. Fairclough has further described modality as 'the dimension of the grammar of the clause which corresponds to the "interpersonal" function of language' (1992:158). This interpersonal function of language addresses the ways in which discourse participants relate to themselves as well as to one another, thereby combining the 'identity' and 'relational' functions of language (Halliday 1978, Fairclough 1992:64-65). I discuss aspects of the interpersonal function of language in the following section to address the ways in which lay judges try to establish social identities as lay judges. This happens through their practices of listening and taking notes of defendants' and witnesses' utterances. Moreover, these linguistic practices are relational, since they take into account other discourse participants in the deliberation room - the judges.

\subsection{Linguistic strategies and their influence on decision-making}

When lay judges explain how they learn to take notice of specific details about how witnesses and defendants talk in the courtroom, they mention that they note down 'key phrases' (LJ6, example (6)), emphasizing 'like word use and that sort of thing, because I think that often during deliberation, it has - it does actually make a bit of a difference' (LJ4, example (8)). Lay Judge 7 (example (7)) also mentions 'when you're sitting in there', referring to the deliberation room. Their actions both implicitly and explicitly address the deliberation situation. Lay judges meticulously write down linguistic details in order to be able to argue with the others during deliberation, and they more or less cite these notes to underscore a point or a stance. These stances presuppose that the other participants in the deliberation room will relate to and evaluate them, and are thus an example of the interpersonal function of language (Fairclough 1992). Lay judges in this sense are not only looking for inconsistencies and hedges in courtroom talk - they are simultaneously trying to show strong affinity with their OWN standpoints by formulating their arguments in ways that they have learnt 'matter' during deliberation. Carefully constructed arguments matter because they may influence the other judges. This strategic use of notes is referred to in the following citation:

(9) LJ8: Det er det jeg mener med, at dommeren ret hurtigt i den her sag ligesom bare kunne pege på, at 'det er en bande, de får et år'. Hvor jeg netop også synes, at når vi sådan går i gang med at tale om det, så gav han sig også lidt på et 
tidspunkt, "nå ja, det var også sådan”. Og det er jo også fordi, at man har nogle noter, man kan forholde sig til.

LJ8: 'That's what I mean, that the judge in this case really quickly like just came out with, "this is a gang, they get one year". But then I think that when we like start talking about it, then he also backed down a bit at some point, "well yes, that's right". And that's because you have some notes you can refer to.' (2. interview, 2013)

The lay judge positions herself in relation to the professional judge and directs her note taking practice towards him. He is the one she must argue with and convince by using her notes.

Notes help put forward different and competing stories about what was said and how it was said - in the courtroom, and they form a negotiation pivot between discourse participants with different professional statuses and knowledge in the deliberation room. Lay judges' note taking as a discourse practice thus highlights its interpersonal function since it helps them set up a social identity for themselves, and contributes to constructing the relationship between lay judges and professional judges (see Fairclough 1992:64).

\section{CONCLUDING DISCUSSION AND PERSPECTIVES}

Although research on American jury note taking has shown that notes might increase jurors' influence during deliberation (Heuer \& Penrod 1988), the present qualitative project does not aim to make any similar claims about the genuine or actual influence of note taking on deliberation situations. However, it would be ill-considered to assume that they do not have any value. In the data studied here, note taking was an activity that supported lay judges in their developing social roles and helped them orient themselves towards the discursive practice that these note taking practices were aimed at.

Lay judges were quite consciously orienting themselves towards their task of deliberating and using appropriate language in a context characterized by specific discourse practices (Fairclough 1992). This broadens our understanding of lay judges, since lay judges have generally been portrayed as powerless speakers vis-à-vis the professional judges (Hans 2003, Machura 2011, Kutnjak Ivković 2015). These communicative asymmetries are equally potent in the present material - after all, lay judges put great effort into matching professional judges by strategically writing and speaking in specific ways. Nevertheless, this also shows us that lay judges are not a static group, since their initial participation gradually develops into a more conscious way of using language as a means of persuasion. Studies of legal communication have focused on how legal professionals address laypersons (Sarat \& 
Felstiner 1995, Heffer 2008, Anesa 2012, several chapters in Heffer, Rock \& Conley 2013), and have often stated that the language of law seems incomprehensible to a lay audience. This translation issue is reversed in the present analysis, since lay judges themselves rephrase their observations to match the legal framework. Further research into lay-legal exchanges might enhance our understanding of how laypersons must also translate their statements in order to become comprehensible to legal professionals.

The project involved a group of 30 lay judges, and I did not find any major differences within this group regarding how 'well' they eventually mastered note taking in this new community of practice. However, Lave \& Wenger (1991) have described how power issues also affect newcomers' paths to a more central membership in a community. Therefore, one might assume that not all lay judges will be able to learn how to exert influence, and that this in turn may be connected to their social class, education, etc. This point calls for further large-scale inquiries into the possibly uneven distribution among lay judges in being able to 'decipher' the linguistic codes of the court.

\subsection{What kind of discursive practice?}

Linguistic anthropologists have given increasing theoretical attention to the concept of language ideology. They have addressed both overt language ideology as in, for instance, how a group perceives appropriate language behaviour (Woolard \& Schieffelin 1994), and more subtle ways of conceiving language as a meta level understanding of 'what it is we are doing when we are speaking' (Mertz 2007:21). Their main point in relation to the present paper is the idea that people conceive of talk and use talk as a self-reflexive action and as a way of orienting themselves as to the kind of language use that fits within a given context - in other words: what kind of discourse? Is it a legal discourse, a mundane, common-sense discourse or something else? Interestingly, Conley \& O'Barr (1990) conclude that jurors apply everyday, unconscious evaluations of witnesses on the basis of their speech styles characterized by either certainty or hesitation (Conley \& O'Barr 1990:67). In a similar vein, Garfinkel (1967) points out that jurors are already $85 \%$ jurors before they even enter the court, implying that jurors just use their common sense and usual way of evaluating people and events in this new context.

These conclusions are somewhat modified by the present empirical findings, though. We clearly see that lay judges themselves reported a marked development in their linguistic practice, and that lay judges wrote briefer but more systematic notes after some years of experience. Lay judges became more 'concise', at least according to what they perceived as a norm, regarding the evaluation of facts and statements by focusing on the way these were coined linguistically. We do not know if these lay judges were unconsciously evaluating defendants' and witnesses' 
speech styles from the outset and then gradually developed a more explicit or meta level understanding of what they were engaging in. However, it seems reasonable to conclude that these discursive practices are not just lay practices, since lay judges learnt to notice the linguistic details by orienting themselves to the professional judge. Lay judges thus found that professional judges themselves employed specific standards when evaluating statements put forward in the courtroom - and in the deliberation room.

Both in the US and Europe, research has shown how law students entering law school are confronted with very specific, but often implicit, legal language norms which they are expected to adopt, as well as a new level of specificity required of them when they describe cases, details and persons (Philips 1988, Mertz 2007, Adrian et al. 2014, Blückert 2015). Although the implicitness of much of this learning resembles what lay judges are presented with in Danish courts, there are of course different professional expectations of lay judges. While law students are expected to take on a professional identity as lawyers, lay judges are subject to the societal ideal that their role is to use common sense when engaging with legal experts. Paradoxically, they seem to have to learn legal specificity in order to efficiently discuss and disagree with professional judges. Though this may not be the kind of legal language that law students learn, neither is it the common-sense approach described in much research about lay participation in the judiciary.

\subsection{Constructing social reality}

Referring to Fairclough's (1992) theory about the interconnectedness of discursive and social practices, one might also ask how lay judges' knowledge of discourses in this legal setting may be related to or affect social practice. Lay judges learn to focus only on information they have found to be important in the court setting. Their ability to learn how linguistic aspects of witness statements can reveal the speaker's affinity with his or her statement, for instance through 'uncertainty', may seem to be a useful skill during decision-making. But as mentioned above, Conley \& O'Barr have analysed how some witnesses express themselves relationally in court and as a consequence appear more inconsistent and less persuasive than lay people who are able to address the courts' rule-oriented language (Conley \& O'Barr 1990). These speech styles reflect social status, gender, and ethnicity, and other social factors. ${ }^{10}$ What Danish lay judges are paying attention to in court may thus not be just uncertainty, but also social markers. In this way, the discursive practices may be closely connected to law's powerful ways of reducing social conflicts to legal problems, trimming away any irrelevant details - and thus also redefining the problems. Geertz has called this process the 'skeletonization of facts' in the sense that facts become 'closely edited diagrams of reality' (Geertz 1983:170-173). This relation between mundane facts and the ways courts condense them can also be 
glimpsed in the present empirical material. Experienced participants in court quickly evaluate evidence such as the possession of cell phones or crumpled banknotes as being either unimportant or containing information reaching beyond the evidence itself. This implies that lay judges may not continue to notice the same details as they did in their first cases, and that instead they use discourse to construct and understand social positions such as 'repeat criminals' or 'drug dealers'.

It is debatable whether this trimming of knowledge and orientation towards 'what courts want' is compatible with the ideal about lay judges' position outside of the judiciary, offering everyday perspectives on issues of right and wrong, facts and punishment. If ignorance is still to be regarded as the true value of lay participation, then this learning process seems to speak against a lay judge system involving lay judges over long periods. From a different perspective, favouring influence over ignorance, there also seem to be benefits from lay judges' recurring experiences with deliberation situations, enhancing their linguistic ability to put forward their own points of view to influence legal outcomes of crucial importance for defendants and victims alike.

\section{ACKNOWLEDGEMENTS}

I would like to thank the anonymous $N J L$ reviewers for their valuable and constructive comments. This work was supported by the Danish Council for Independent Research [0602-02291B].

\section{NOTES}

1. In serious cases, an extended lay court is used, consisting of three professional judges and six lay judges. In order to convict a person, four of the lay judges and two of the professional judges have to find the person guilty. They deliberate together.

2. Persons employed in the public administration and in certain legal positions are excluded.

3. Recruitment of lay judges has until recently consisted of electing citizens affiliated to a political party. This procedure has been broadened to meet requirements for a more diversified socio-demographic composition.

4. Although all but one of the observed cases included defendants and witnesses who spoke Danish (the official language of the courts), it should be mentioned that criminal cases involving non-Danish speakers are provided with interpreters. These interpreted testimonies may cause language problems - probably also for lay judges - because of their (hotly debated) quality, but this aspect lies beyond the scope of the present article.

5. My analysis is based on a coding practice that emerged through repeated reading of interview transcripts and field notes. The initial coding was open in order to identify themes without imposing them from the outset, and was followed by a more selective coding before detailed analysis was conducted. 
6. Fairclough considers the description of the linguistic aspects of texts as closely related to the interpretation of discursive and social practices, since the description will always be influenced by the adopted discursive framework (1992:198-199).

7. Consequently, I was not directly able to analyse these notes as texts.

8. A related criticism has been voiced concerning debates about American jurors' possible note taking, since it was expected to distract them and lead them to oversee important facts (Heuer \& Penrod 1988).

9. The Danish word meget 'very' in this context is difficult to translate into English but signals a reservation that is best expressed by a modal adverb such as probably.

10. Although Conley \& O'Barr's (1990) data were ground-breaking when collected in the 1980 s, they may need an update concerning contemporary connections between social privilege and credibility in legal contexts.

\section{REFERENCES}

Adrian, Lin, Louise Victoria Johansen, Anne Lise Kjær \& Katrine Meldgaard Kjær. 2014. Imagining law: A pilot study of entering law students' discourse about law, legal education and legal professions. Retferd 3, 63-85.

Anderson, Stanley. 1990. Lay Judges and Jurors in Denmark. American Journal of Comparative Law 38, 839-864.

Anesa, Patrizia. 2012. Jury Trials and the Popularization of Legal Language: A Discourse Analytical Approach. Bern New York: Peter Lang.

Atkinson, John \& Paul Drew. 1979. Order in Court: The Organization of Verbal Interaction in Judicial Settings. Atlantic Highlands, NJ: Humanities Press.

Blückert, Ann. 2015. Juridikstudenters språkliga inskolning. In Anne Lise Kjær, Lin Adrian, Cecilie B. Cederstrøm, Jan Engberg, Jonas Gabrielsen, Morten Rosenmeier \& Steen Schaumburg-Müller (eds.), Retten $i$ sproget. Samspillet mellem ret og sprog $i$ juridisk praksis. Copenhagen: Jurist- og Økonomforbundets Forlag.

Chase, Susan. 1995. Taking narratives seriously: Consequences for method and theory. In Ruthellen Josselson \& Amia Lieblich (eds.), Interpreting Experience: The Narrative Study of Lives, 1-26. London: Sage.

Conley, John M. \& William O'Barr. 1990. Rules versus Relationships: The Ethnography of Legal Discourse. Chicago, IL \& London: University of Chicago Press.

Conley, John M., William M. O'Barr \& E. Allan Lind. 1978. The Power of Language: Presentational Style in the Courtroom. Duke Law Journal 1978, 1375-1399.

Conley, Robin H. \& John M. Conley. 2009. Stories from the jury room: How jurors use narrative to process evidence. Studies in Law, Politics and Society 49, 25-56.

Diamond, Shari, Neil Vidmar, Mary Rose \& Leslie Ellis. 2003. Inside the jury room: Evaluating juror discussions during trial. Judicature 87(2), 54-59.

Diesen, Christian. 1996. Lekmän som domare. Stockholm: Juristförlaget.

Eyben, W. E. v. 1969. Den danske retspleje vurderet af ikke-jurister. In O. A. Borum, A. Graff \& W. E. v. Eyben (eds.), Retsplejeloven gennem 50 år. Copenhagen: Juristforbundet.

Fairclough, Norman. 1992. Discourse and Social Change. Cambridge: Polity.

Fairclough, Norman. 2003. Analysing Discourse, Textual Analysis for Social Research. London: Routledge.

Flango, V. E. 1980. Would jurors do a better job if they could take notes? Judicature 63, 436-443. 
Garfinkel, Harold. 1967. Studies in Ethnomethodology. Englewood Cliffs, NJ: Prentice-Hall.

Geertz, Clifford. 1983. Local Knowledge, Further Essays in Interpretive Anthropology. New York: Basic Books.

Halliday, M. A. K. 1978. Language as Social Semiotic: The Social Interpretation of Language and Meaning. London: Edward Arnold.

Halliday, M. A. K. 1994. An Introduction to Functional Grammar. London: Edward Arnold.

Hans, Valerie P. 2003. Introduction: Lay participation in legal decision making. Law \& Policy 25, 83-92.

Heffer, Chris. 2008. The language and communication of jury instructions. In John Gibbons \& Teresa Turell (eds.), Dimensions of Forensic Linguistics. Amsterdam \& Philadelphia, PA: John Benjamins.

Heffer, Chris, Frances Rock \& John M. Conley (eds.). 2013. Legal-lay Communication: Textual Travels in The Law. New York: Oxford University Press.

Heuer, Larry \& Steven [D.] Penrod. 1988. Increasing jurors' participation in trials. Law and Human Behavior 12, 231-261.

Heuer, Larry \& Steven D. Penrod. 1989. Instructing jurors. Law and Human Behavior 13, 409-430.

Hymes, Dell. 1971. Sociolinguistics and the ethnography of speaking. In Edward Ardener (ed.), Social Anthropology and Language, 47-94. London: Tavistock.

Johansen, Louise Victoria. 2017. Fra novice til oldtimer - domsmandsrollen som læringsproces. Nordisk Tidsskrift for Kriminalvidenskab 104, 241-258.

Kuhn, Deanna, Michael Weinstock \& Robin Flaton. 1994. How well do jurors reason? Competence dimensions of individual variation in a juror reasoning task. Psychological Science 5, 289-296.

Kutnjak Ivković, S. 2015. Ears of the deaf: The theory and reality of lay judges in mixed tribunals. Chicago-Kent Law Review 90, 1031-1067.

Lave, Jean \& Etienne Wenger. 1991. Situated Learning. Cambridge: Cambridge University Press.

Lundmark, Thomas. 2012. Lay Judges and Juries: Charting the Divide between Common and Civil Law. Oxford: Oxford University Press.

Machura, Steven. 2011. Silent lay judges: Why their influence in the community falls short of expectations. Chicago-Kent Law Review 86, 769-788.

Malsch, Marijke. 2009. Democracy in the Courts: Lay Participation in European Criminal Justice Systems. Farnham: Ashgate.

Manzo, John F. 1994. You wouldn't take seven-year-old and ask him all these questions: Jurors' use of practical reasoning in supporting their arguments. Law and Social Inquiry 19(3), 639-666.

McLaughlin, M. A. 1982. Questions to witnesses and notetaking by the jury as aids in understanding complex litigation. New England Law Review 18, 687-713.

Merry, Sally Engle. 1990. Getting Justice and Getting Even: Legal Consciousness Among Working-Class Americans. Chicago, IL \& London: University of Chicago Press.

Mertz, Elisabeth. 2007. The Language of Law School: Learning to "Think Like a Lawyer". Oxford: Oxford University Press.

Mortensen, Sune Sønderberg \& Janus Mortensen. 2017. Epistemic stance in courtroom interaction. In Francesca Poggi \& Alessandro Capone (eds.), Pragmatics and Law: Practical and Theoretical Perspectives, 401-437. Cham: Springer.

O'Barr, William M. 1982. Linguistic Evidence: Language, Power, and Strategy in The Courtroom. New York: Academic Press. 
Pennington, Nancy \& Reid Hastie. 1991. A cognitive theory of juror decision making: The story model. Cardozo Law Review 13, 519-557.

Philips, Susan [U]. 1988. The language socialization of lawyers: Acquiring the "cant". In George Spindler (ed.), Doing the Ethnography of Schooling: Educational Anthropology in Action, 176-209. Prospect Heights, NY: Waveland.

Philips, Susan U. 1993. Evidentiary standards for American trials: Just the facts. In Jane H. Hill \& Judith T. Irvine (eds.), Responsibility and Evidence in Oral Discourse, 248-259. Cambridge: Cambridge University Press.

Philips, Susan U. 2010. Identity construction in powerful institutions: A commentary. Critical Inquiry in Language Studies 7, 230-235.

Piecker, Shelley C. \& Debra Worthington. 2003. The influence of opening statement/closing argument organizational strategy on juror verdict and damage awards. Law and Human Behavior 27, 437-456.

Sarat, Austin \& William L. F. Felstiner. 1995. Divorce Lawyers and their Clients: Power and Meaning in the Legal Process. Oxford: Oxford University Press.

Tamm, Ditlev. 2008. Scandinavian Law. In Peter Cane \& Joanne Conaghan (ed.), The New Oxford Companion to Law, 195-196. Oxford: Oxford University Press.

Warren, Joshua, Deanna Kuhn \& Michael Weinstock. 2010. How do jurors argue with one another? Judgment and Decision Making 5, 64.

Wilhjelm, Preben. 1988. Folkevalgte dommere. Copenhagen: University of Copenhagen.

Woolard, Kathryn A. \& Bambi B. Schieffelin. 1994. Language ideology. Annual Review of Anthropology 23, 55-82. 